\title{
Paclobutrazol Reduces Photosynthetic Carbon Dioxide Uptake Rate in Grapevines
}

\author{
David M. Hunter \\ Agriculture Canada Research Branch, Research Station. Harrow, Ont. NOR 1G0, Canada \\ John T.A. Proctor \\ University of Guelph, Department of Horticultural Science, Guelph, Ont. N1G 2W1, Canada
}

Additional index words. Vitis, growth regulator, growth inhibitor, growth retardant, PP333, soil-applied

\begin{abstract}
Paclobutrazol applied as a soil drench at 0, 1, 10, 100, or $1000 \mu \mathrm{g}$ a.i./g soil reduced photosynthetic $\mathrm{CO}_{2}$ uptake rate of leaves formed before paclobutrazol treatment within 3 to 5 days of treatment and the reductions were maintained for 15 days after treatment. The percentage of recently assimilated ${ }^{14} \mathrm{C}$ exported from the source leaf was reduced only at the highest paclobutrazol dose, and there was little effect of treatment on the partitioning of exported ${ }^{14} \mathrm{C}$ between the various sinks. In response to increasing doses of paclobutrazol, particularly at the higher doses, an increasing proportion of recent photoassimilates was maintained in a soluble form in all plant components. Reduced demand for photoassimilates as a result of the inhibition of vegetative growth may have contributed to a reduction in photosynthetic $\mathrm{CO}_{2}$ uptake rate, but this reduction in photosynthesis rate could not be attributed to a feedback inhibition caused by a buildup of starch in the leaves. Paclobutrazol had only a minor effect, if any, on photosynthetic electron transport. Chemical name used: $\beta$-[(4-chlorophenyl) methyl]- $\alpha$-(1,1-dimethylethyl)-1H-1,2,4-triazole-1-ethanol (paclobutrazol).
\end{abstract}

Changes in grapevine canopy structure directly affect growth, productivity, and fruit quality through changes in processes such as solar radiation absorption and exchange of $\mathrm{CO}_{2}, \mathrm{O}_{2}$, and water vapor. Paclobutrazol modified canopy structure in the interspecific grape (Vitis spp.) cultivar Seyval blanc by inhibiting growth of the main shoot apex and of axillary buds and shoots (Hunter and Proctor, 1992). After summer pruning, lateral shoot development of 'Riesling' (Vitis vinifera L.) vines was also inhibited by paclobutrazol (Reynolds, 1988). Lateral shoot development depended on the parent shoot for photoassimilates until the axillary shoot had attained two or three fully expanded leaves (Hale and Weaver, 1962; Koblet, 1977). With the suppression of lateral growth, whole-plant $\mathrm{CO}_{2}$ uptake was decreased by the reduction in total leaf area (Williams et al., 1989), thus contributing to lower fruit quality after paclobutrazol treatment (Hunter and Proctor, 1992; Shaltout et al., 1988; Williams et al., 1989). However, Reynolds (1988) reported improved fruit quality after paclobutrazol application and suggested that the reduction in photoassimilate demand for vegetative growth enabled developing fruit clusters to obtain a greater proportion of recent photoassimilates. Similarly, Wood (1984) attributed a general increase in carbohydrate concentration in paclobutrazol-treated pecan seedlings to the reduced demand for carbohydrates for vegetative growth.

Sugar beet leaves formed after paclobutrazol treatment typically were smaller, thicker, and darker green; increases in chlorophyll concentration per unit leaf area likely accounted for higher rates of photosynthesis (Jaggard et al., 1982). For leaves developing after paclobutrazol treatment, other workers have reported a slight increase (Wood, 1984), no effect (DeJong and Doyle, 1984), or a reduction (Vu and Yelenosky, 1992; Wample and Culver, 1983 ) in photosynthetic $\mathrm{CO}_{2}$ uptake rate.

Photosynthetic $\mathrm{CO}_{2}$ uptake rate responded to changes in assimilate demand (Guinn and Mauney, 1980; Neales and Incoll, 1968).

Received for publication 8 Feb. 1993. Accepted for publication 2 July 1993. We gratefully acknowledge the gift of paclobutrazol from Chipman. The cost of publishing this paper was defrayed in part by the payment of page charges. Under postal regulations, this paper therefore must be hereby marked advertisement solely to indicate this fact.
The grapevine, a perennial plant, allocates part of its photoassimilates into storage carbohydrates that can be mobilized under stress (Koblet, 1985; Mansfield and Howell, 1981), thus providing for some buffering of the photoassimilate demands.

In the present study, a simplified test-plant system (Hunter and Proctor, 1990) was used to investigate the effects of paclobutrazol on canopy structure by measuring photosynthesis and photoassimilate partitioning in 'Seyval blanc' grapevines. This included measuring how photoassimilate production and distribution were influenced after paclobutrazol application. Grapevine canopy manipulation using paclobutrazol may improve or increase production, reduce inputs, improve fruit quality, hasten maturity, and improve synchrony of ripening.

\section{Materials and Methods}

The simplified plant system used consisted of roots, stem, and a single retained leaf with its axillary bud (Hunter and Proctor, 1990). Plants were grown in a growth chamber maintained at 25/ $20 \pm 2 \mathrm{C}$ (day/night), a 16-h photoperiod, and a photosynthetic photon flux (PPF) of 500 to $800 \mu \mathrm{mol} \cdot \mathrm{m}^{-2} \cdot \mathrm{s}^{-1}$ at the level of the retained leaf. When the axillary bud started to develop into a leafy shoot, net photosynthetic $\mathrm{CO}_{2}$ uptake rate was determined on the retained leaf using a closed gas-exchange portable photosynthesis system (LI-6000; LI-COR, Lincoln, Neb.) equipped with a 1-liter leaf chamber set up in a fixed location. The use of inserts in the leaf chamber maintained a rectangular area of the leaf under test that ranged from 12 to $18 \mathrm{~cm}^{2}$ depending on the experiment. Wellwatered plants were preconditioned for $60 \mathrm{~min}$ by placing them under high-pressure sodium (HPS) lamps supplying a PPF of $\approx 1000 \mu \mathrm{mol} \cdot \mathrm{m}^{-2} \cdot \mathrm{s}^{-1}$ at the leaf level as measured with a quantum sensor (LI-190S; LI-COR). All photosynthesis measurements were made at a leaf-level PPF of 1050 to $1100 \mu \mathrm{mol} \cdot \mathrm{m}^{-2} \cdot \mathrm{s}^{-1}$ provided by HPS lamps. A water bath 3 to $4 \mathrm{~cm}$ deep placed between the light source and the leaf chamber absorbed infrared radiation, thus preventing excessive heating of the leaf chamber, which could be maintained at a temperature of 27 to $30 \mathrm{C}$ during measurements. The leaf was allowed to acclimate in the leaf chamber for $\approx 30 \mathrm{sec}$. Data were logged for $40 \mathrm{sec}$, during which 
time $\mathrm{CO}_{2}$ concentration in the leaf chamber was reduced by 15 to $20 \mu \mathrm{l} \cdot$ liter $^{-1}$ from $\approx 330 \mu \mathrm{l} \cdot$ liter $^{-1}$ (ambient).

Photosynthesis measurements made on day 0 before treatments were ranked and used to allocate plants to replicates, and treatments were then randomized within replicates. Paclobutrazol was applied as a soil drench to provide 0 (control), 1 (treatment 1$), 10$ (treatment 2), 100 (treatment 3), or 1000 (treatment 4) $\mu$ g a.i./g soil mix, as previously described (Hunter and Proctor, 1990). Photosynthesis rates were determined for 15 days after paclobutrazol treatment. Plants were harvested on day 15 to determine fresh and dry weights.

An open stationary photosynthesis system (Proctor et al., 1982) was used to determine light response curves of the retained leaf on day 7 after treatment with paclobutrazol. Leaf chamber temperature was $25 \pm 1 \mathrm{C}$ and $\mathrm{CO}_{2}$ concentration of the air supply was maintained at $330 \mu \mathrm{l} \cdot \mathrm{liter}^{-1}$. PPF at the leaf level was controlled by placing screens made of commercial metal window screening, painted flat black, between the light source and the water bath and monitored with a quantum sensor (LI-190S; LI-COR). Plants were held for a minimum of $4 \mathrm{~h}$ in darkness to lower leaf carbohydrate reserves before preconditioning in the laboratory at a PPF of 800 to $900 \mu \mathrm{mol} \cdot \mathrm{m}^{-2} \cdot \mathrm{s}^{-1}$ for $\approx 90 \mathrm{~min}$. The leaf was then placed in the cuvette and exposed to the highest PPF of $1100 \mu \mathrm{mol} \cdot \mathrm{m}^{-2} \cdot \mathrm{s}^{-1}$. When the $\mathrm{CO}_{2}$ differential between the reference and sample cells of the infrared gas analyzer stabilized (after $\approx 60 \mathrm{~min}$ ), readings were taken and PPF was reduced by inserting screens between the light source and water bath. After each reduction in PPF, $\mathrm{CO}_{2}$ levels were allowed to stabilize before readings were taken. PPFs used in this study were $1100,750,500,350,150$, and $0 \mu \mathrm{mol} \cdot \mathrm{m}^{-2} \cdot \mathrm{s}^{-}$ ${ }^{1}$, the last being obtained by covering the entire cuvette with a black felt cloth. The leaf area under test was determined using a leaf area meter (LI-3100; LI-COR).

On day 7 after paclobutrazol treatment, two leaf disks (each 1 $\mathrm{cm}$ in diameter) were cut from the petiolar lobes of the retained leaf. Sufficient leaf area was retained undisturbed to enable photosynthesis measurements to be made through to harvest on day 15 . The leaf disks were extracted in boiling $80 \%$ ethanol and the extracts were assayed for reducing sugars using the anthrone method (Grant and Ryugo, 1984). To estimate leaf starch content, the residue after ethanol extraction was incubated for $4 \mathrm{~h}$ at $42 \mathrm{C}$ with amyloglucosidase (1,4, $\alpha$-D-glucan-glucohydrolase, Sigma Chemical Co., St. Louis) in sodium acetate buffer (pH4.5), and the supernatant was assayed for reducing sugars using anthrone. Results from these assays are reported as glucose equivalents.

At the end of the photoperiod on day 7, plants were placed in a darkroom for $12 \mathrm{~h}$ (overnight). Chlorophyll fluorescence was determined using a plant productivity fluorometer (model SF-20; Richard Brancker Research, Ottawa). During the measurements, the darkroom was illuminated with a low-intensity green light (40W bulb with a Kodak Safelight filter no. 7). The leaf was placed with its abaxial surface on a flat black felt surface. The fluorometer probe was held against the adaxial leaf surface for $20 \mathrm{sec}$ before readings were taken. The initial, peak, and terminal (after $50 \mathrm{sec}$ ) readings were recorded from the digital displays. Three observations were made on different locations of each leaf, in each case avoiding placing the probe on major veins or the midrib.

Distribution of ${ }^{14} \mathrm{C}$-labeled photoassimilates in the test plant system was determined after the photoassimilation of ${ }^{14} \mathrm{CO}_{2}$ by the retained leaf on day 7 after treatment with paclobutrazol. Plants were preconditioned for $45 \mathrm{~min}$ under a PPF of $1000 \mu \mathrm{mol} \cdot \mathrm{m}^{-2} \cdot \mathrm{s}^{-}$ ${ }^{1}$. The leaf was then sealed in a leaf chamber in a closed system (Ursino et al., 1982) and exposed to $\approx 370 \mathrm{kBq}{ }^{14} \mathrm{CO}_{2}$ liberated by adding $2 \mathrm{ml}$ lactic acid to $0.1 \mathrm{ml} \mathrm{Na}_{2}{ }^{14} \mathrm{CO}_{3}$ in dilute $\mathrm{NaOH}$ (specific activity $\approx 3.7 \mathrm{MBq} \cdot \mathrm{ml}^{-1}$. A PPF of $1100 \mu \mathrm{mol} \cdot \mathrm{m}^{-2} \cdot \mathrm{s}^{-1}$ at the level of the leaf in the leaf chamber was provided by HPS lights with water bath as described earlier. The leaf was removed from the leaf chamber, and the plant was placed under a PPF of $1000 \mu \mathrm{mol} \cdot \mathrm{m}^{-}$ ${ }^{2} \cdot \mathrm{s}^{-1}$ for a $24-\mathrm{h}$ chase period, except for a 10 -h dark period. Plants were harvested $24 \mathrm{~h}$ after the initial ${ }^{14} \mathrm{CO}$ feeding and separated into fed leaf, petiole, axillary shoot, main stem, and root components. Leaf areas of the fed leaf and axillary leaves were determined using the leaf area meter. After fresh weights were determined, each component was chopped into smaller pieces, placed in test tubes, and frozen over a dry-ice-methanol mix. Components were stored in a freezer before drying under vacuum to determine dry weights. The dried components were then extracted three times in boiling $80 \%$ ethanol. Duplicate aliquots $(100 \mu \mathrm{l})$ of the ethanol extract were counted in $10 \mathrm{ml}$ scintillation fluid (ReadySolv HP; Beckman Canada, Mississauga, Ont.) in a liquid scintillation counter (model 1800; Beckman Canada). After redrying, the residues were combusted in an $\mathrm{O}_{2}$ atmosphere to liberate retained ${ }^{14} \mathrm{C}$ as ${ }^{14} \mathrm{CO}_{2}$. After cooling, 10 to $15 \mathrm{ml} 1$ phenylethylamine : 1 methanol was added to absorb the ${ }^{14} \mathrm{CO}_{2}$ (Gaynor, 1984). Duplicate aliquots $(100 \mu \mathrm{l})$ were counted in $10 \mathrm{ml} 0.8 \%$ 2,5-diphenyloxazole in toluene in the liquid scintillation counter. Counting efficiencies were determined by internal standardization using ${ }^{14} \mathrm{C}$-n-hexadecane $\left(0.872 \times 10^{6}\right.$ disintegrations/min per $\left.\mathrm{ml}\right)$. All radioisotopes used for this study were purchased from Amersham Corp. (Oakville, Ont.).

Experiments were designed as randomized complete blocks with four to six replicates. Data were analyzed using SAS's general linear models procedure (SAS Institute, Cary, N.C.), and treatment means were separated using single degree of freedom contrasts (Snedecor and Cochran, 1980). Treatment means are presented with $1 \mathrm{SE}$. Differences between treatments are reported as nonsignificant or as significant at $P=0.05,0.01$, or 0.001 . Curve fitting of the photosynthetic light response curves was performed using the maximum likelihood program (MLP) (Ross, 1987).

\section{Results}

Although there were differences between the control and the lowest dose of paclobutrazol $\left(1 \mu \mathrm{g} \cdot \mathrm{g}^{-1}\right.$ soil) in growth (fresh and dry weight) of the axillary shoot (Hunter and Proctor, 1990), there was no difference between these two treatments with regard to net photosynthetic $\mathrm{CO}_{2}$ uptake rate (Fig. 1). For all other doses of paclobutrazol, net photosynthetic $\mathrm{CO}_{2}$ uptake rate was reduced within 2 days of paclobutrazol application (Fig. 1). By 5 days after treatment, the reductions in net photosynthetic $\mathrm{CO}_{2}$ uptake rate were $\approx 20 \%, 40 \%$, and $60 \%$ at the 10,100 , and $1000 \mu \mathrm{g}$ a.i./g soil doses, respectively. These reductions in Pn were maintained for 15 days after treatment.

Photosynthetic light response data obtained on day 7 after treatment were analyzed for each PPF. At the higher PPFs (350 to $\left.1100 \mu \mathrm{mol} \cdot \mathrm{m}^{-2} \cdot \mathrm{s}^{-1}\right)$, there was a highly significant $(P=0.001)$ linear decrease in photosynthetic $\mathrm{CO}_{2}$ uptake in response to logscale increases in paclobutrazol dose (Fig. 2). At a lower PPF (150 $\left.\mu \mathrm{mol} \cdot \mathrm{m}^{-2} \cdot \mathrm{s}^{-1}\right)$, the linear decrease in photosynthesis rate was significant at $P=0.05$, while in the dark $(P P F=0)$, there were no significant differences between treatments.

The data for each treatment were fitted to an asymptotic exponential $\left(\mathrm{y}=\mathrm{a}+\mathrm{be}^{-\mathrm{kx}}\right)$ using MLP (Ross, 1987), and the parameters of the fitted curves are presented in Table 1. Using parallel curve analysis under MLP to test for differences between the fitted curves, there was a highly significant $(P=0.001)$ effect of paclobutrazol dose on the photosynthetic light response curve. Photosynthetic efficiency, i.e., the initial slope of the photosyn- 


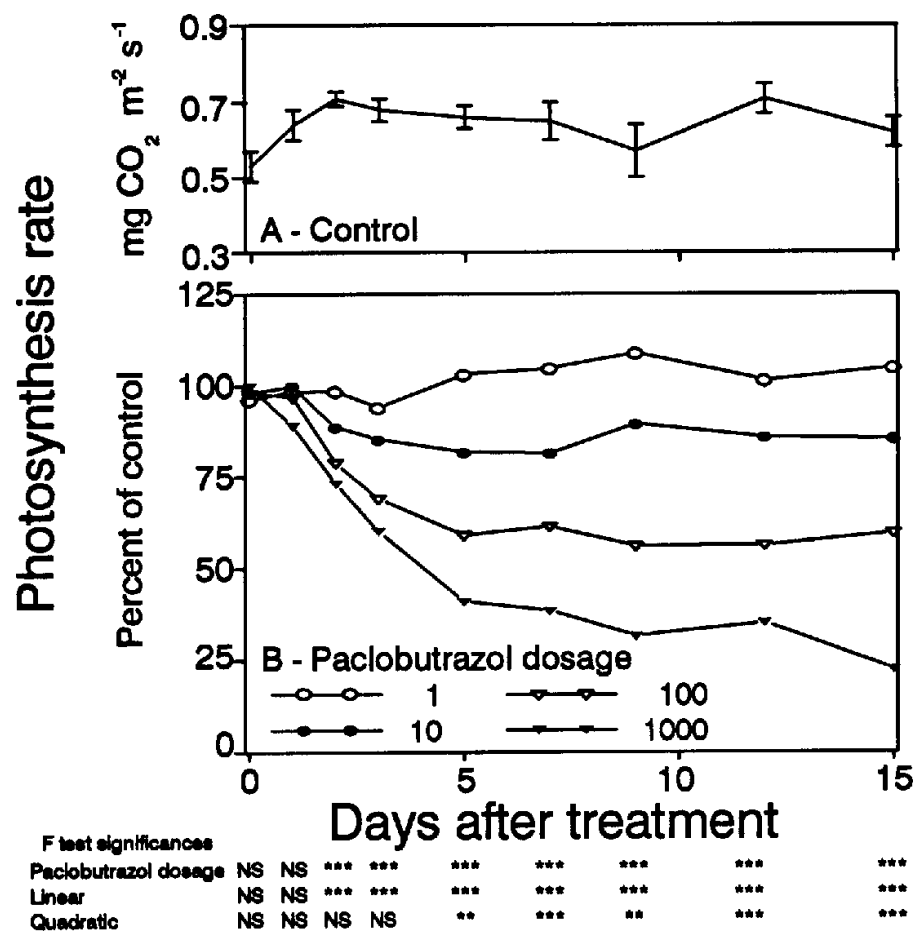

Fig. 1. Photosynthesis rates of 'Seyval blanc' grape leaves following soil application of paclobutrazol at (A) $0 \mu \mathrm{g}$ a.i./g soil (control) (vertical bars indicate SE) or (B) 1, 10, 100, or $1000 \mu \mathrm{g}$ a.i./g soil, expressed as percentage of control. Ns, ${ }^{* * * * * *}$ Nonsignificant or significant at $P=0.01$ or 0.001 , respectively.

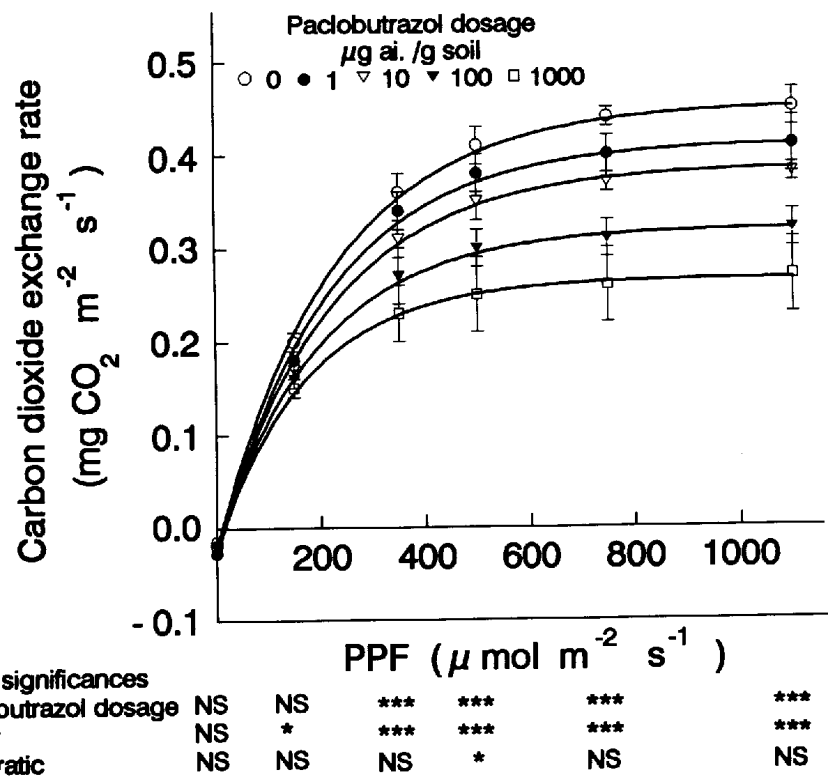

Fig. 2. Photosynthetic light response curves $\left(y=a+b e^{-k x}\right)$ of 'Seyval blanc' grape leaves observed on day 7 after soil application of paclobutrazol at 0, 1, 10, 100, or $1000 \mu \mathrm{g}$ a.i./g soil. Vertical bars indicate SE. ${ }^{\mathrm{Ns},{ }^{*}, * * *}$ Nonsignificant or significant at $P=0.05$ or 0.001 , respectively.

thetic light response curve (France and Thornley, 1984), declined in response to increasing doses of paclobutrazol (Table 1). The light saturation point also declined with increasing doses of paclobutrazol, from $830 \mu \mathrm{mol} \cdot \mathrm{m}^{-2} \cdot \mathrm{s}^{-1}$ for control plants to 600 $\mu \mathrm{mol} \cdot \mathrm{m}^{-2} \cdot \mathrm{s}^{-1}$ for plants treated with the highest dose of paclobutrazol (1000 $\mu$ g a.i./g soil). No significant or consistent differences were noted in dark respiration $\left(\mathrm{CO}_{2}\right.$ exchange rate when $\left.\mathrm{PPF}=0\right)$ and in light compensation point $\left(\mathrm{PPF}\right.$ when net $\mathrm{CO}_{2}$ exchange rate
$=0)$.

The concentration of ethanol-extracted carbohydrate showed a linear $(P=0.01)$ decrease in response to log-scale increases in paclobutrazol dose (Table 2). Starch levels, as estimated by the insoluble carbohydrate concentration, showed a linear $(P=0.001)$ and quadratic $(P=0.05)$ decrease in response to log-scale increases in paclobutrazol doses, as did total carbohydrate concentration (Table 2). The ratio between soluble and insoluble carbohydrates increased with increasing paclobutrazol doses.

While photosynthetic $\mathrm{CO}_{2}$ uptake on day 7 after paclobutrazol treatment was inhibited by increasing paclobutrazol doses (Figs. 1 and 2), no treatment differences were observed for the initial and peak leaf chlorophyll fluorescence readings (Table 3). For the terminal (after $50 \mathrm{sec}$ ) reading, however, there was a significant linear $(P=0.01)$ and quadratic $(P=0.05)$ response to log-scale increases in paclobutrazol concentration. As the dose of paclobutrazol applied increased from 0 to $100 \mu \mathrm{g} \cdot \mathrm{g}^{-1}$ soil, the terminal fluorescence reading increased from $\approx 54$ to $57 \mathrm{~mA}$, then declined at the highest paclobutrazol dose to $55 \mathrm{~mA}$.

Assimilated ${ }^{14} \mathrm{C}$ was recovered separately from the various plant components and total recovery was calculated (Table 4). Higher recoveries were obtained from the plants that received the lower doses of paclobutrazol (10 and $1 \mu \mathrm{g}$ a.i./g soil), while the plants that received the highest paclobutrazol dose $(1000 \mu \mathrm{g}$ a.i./ $\mathrm{g}$ soil) yielded the lowest recovery of ${ }^{14} \mathrm{C}$. In a preliminary study with a 2 -h translocation period, ${ }^{14} \mathrm{C}$ recovery from plants treated with paclobutrazol at 10,100 , and $1000 \mu \mathrm{g} \cdot \mathrm{g}^{-1}$ soil, decreased to $87 \%, 58 \%$, and $31 \%$ of the control, respectively (data not presented). Recovery of ${ }^{14} \mathrm{C}$ in the ethanol extract exceeded recovery from combustion of the residue after ethanol extraction, and the ratio of ethanol-soluble to ethanol-insoluble ${ }^{14} \mathrm{C}$ recovered on a whole-plant basis increased with increasing paclobutrazol dose (Table 4). Within each plant component, the ratio of ethanolsoluble to ethanol-insoluble ${ }^{14} \mathrm{C}$ increased with increasing paclobutrazol dose (Table 4).

Exported ${ }^{14} \mathrm{C}$ was calculated as the summation of ${ }^{14} \mathrm{C}$ recovered from the petiole, axil, main stem, and roots, i.e., the ${ }^{14} \mathrm{C}$ recovered from all plant parts except the fed leaf. In the preliminary study, $<5 \%$ of the recovered ${ }^{14} \mathrm{C}$ was exported from the fed leaf (data not presented), while with a $24-\mathrm{h}$ translocation period, $>50 \%$ of the recovered ${ }^{14} \mathrm{C}$ was exported (Table 4$)$. At the highest paclobutrazol dose (1000 $\mu \mathrm{g}$ a.i./g soil), $55 \%$ of the recovered ${ }^{14} \mathrm{C}$ was exported from the fed leaf, while for the other treatments (control and 1, 10, and $100 \mu \mathrm{g}$ a.i./g soil), $70 \%$ of the recovered ${ }^{14} \mathrm{C}$ was exported from the fed leaf (Table 4).

About $75 \%$ to $80 \%$ of the exported ${ }^{14} \mathrm{C}$ was partitioned between the axillary shoot and the roots, while the main stem retained $\approx 20 \%$ and the petiole $<4 \%$ of the exported ${ }^{14} \mathrm{C}$ (Table 5). Control plants had the highest percentage of export to the axillary shoot but the lowest percentage of export to the roots (Table 5). No significant effect of paclobutrazol was noted for the main stem component. Although the petiole contained $<4 \%$ of the exported ${ }^{14} \mathrm{C}$, log-scale increases in paclobutrazol dose resulted in a significant linear increase $(P=0.001)$ in percentage of exported ${ }^{14} \mathrm{C}$ recovered from this component.

\section{Discussion}

Soil applications of paclobutrazol inhibited axillary shoot growth of the modified test plant system; the effect was evident within a few days of application (Hunter and Proctor, 1990). With a reduction in shoot growth after paclobutrazol application, it was anticipated that demand for photoassimilates by the sinks, particu- 
Table 1. Parameters of fitted photosynthesis light response curves $\left(\mathrm{y}=\mathrm{a}+\mathrm{b} \mathrm{e}^{-\mathrm{kx}}\right)$ and estimated values for dark respiration, photosynthetic efficiency, light compensation point, and light saturation point.

\begin{tabular}{|c|c|c|c|c|c|}
\hline \multirow[b]{2}{*}{ Variable } & \multicolumn{5}{|c|}{ Paclobutrazol dosage ( $\mu$ g a.i./g soil) } \\
\hline & 0 & 1 & 10 & 10 & 1000 \\
\hline \multicolumn{6}{|l|}{ Parameter } \\
\hline $\mathrm{a}$ & 0.45403 & 0.41282 & 0.38755 & 0.32121 & 0.26708 \\
\hline $\mathrm{b}$ & -0.47623 & -0.44382 & -0.41125 & -0.34293 & -0.29099 \\
\hline $\mathrm{k}$ & 0.00445 & 0.00471 & 0.00458 & 0.00509 & 0.00580 \\
\hline$R^{2}$ & 0.991 & 0.955 & 0.958 & 0.920 & 0.793 \\
\hline Significance & $* * *$ & $* * *$ & $* * *$ & $* * *$ & $* * *$ \\
\hline \multicolumn{6}{|l|}{ Estimated values } \\
\hline Dark respiration $\left(\mathrm{mg} \mathrm{CO}_{2} / \mathrm{m}^{2}\right.$ per sec $)$ & 0.022 & 0.031 & 0.024 & 0.022 & 0.024 \\
\hline Efficiency $(\mathrm{mg} \mathrm{CO} / \mu \mathrm{mol})$ & 0.00212 & 0.00209 & 0.00188 & 0.00174 & 0.00169 \\
\hline Compensation point $\left(\mu \mathrm{mol} \cdot \mathrm{m}^{-2} \cdot \mathrm{s}^{-1}\right)$ & 10.7 & 15.4 & 13.0 & 12.9 & 14.8 \\
\hline Saturation point $\left(\mu \mathrm{mol} \cdot \mathrm{m}^{-2} \cdot \mathrm{s}^{-1}\right)$ & 830 & 780 & 780 & 680 & 600 \\
\hline
\end{tabular}

**** Significant at $P=0.001$.

Table 2. Carbohydrate levels, as glucose equivalents, of 'Seyval blanc' grape leaves 7 days after soil application of paclobutrazol at 0 (control), 1 (treatment 1), 10 (treatment 2), 100 (treatment 3), or 1000 (treatment 4) $\mu \mathrm{g}$ a.i./g soil.

\begin{tabular}{lccccc}
\hline \hline & & \multicolumn{4}{c}{ Carbohydrate levels $\left(\mu \mathrm{g} \cdot \mathrm{cm}^{-2}\right)$} \\
\cline { 3 - 6 } Treatment & & Soluble $^{\mathrm{z}}$ & Insoluble $^{\mathrm{y}}$ & Total & Ratio $^{\mathrm{x}}$ \\
\hline Control & Mean & 0.78 & 0.84 & 1.62 & 0.98 \\
& $\mathrm{SE}$ & 0.04 & 0.06 & 0.09 & 0.09 \\
1 & Mean & 0.72 & 0.82 & 1.53 & 0.91 \\
& $\mathrm{SE}$ & 0.04 & 0.05 & 0.07 & 0.06 \\
2 & $\mathrm{Mean}$ & 0.74 & 0.79 & 1.52 & 0.98 \\
& $\mathrm{SE}$ & 0.06 & 0.06 & 0.09 & 0.09 \\
3 & $\mathrm{Mean}$ & 0.73 & 0.60 & 1.33 & 1.26 \\
& $\mathrm{SE}$ & 0.05 & 0.05 & 0.09 & 0.11 \\
4 & $\mathrm{Mean}$ & 0.64 & 0.43 & 1.08 & 1.51 \\
& $\mathrm{SE}$ & 0.05 & 0.03 & 0.07 & 0.11 \\
Significance & & $* *$ & $* * *$ & $* * *$ & $* * *$ \\
Linear & & $* *$ & $* * *$ & $* * *$ & $* * *$ \\
Quadratic & & $\mathrm{NS}$ & $*$ & $*$ & $*$ \\
\hline
\end{tabular}

${ }^{\mathrm{z} E t h a n o l-e x t r a c t a b l e ~ c a r b o h y d r a t e s . ~}$

${ }^{\mathrm{y}}$ Residue following ethanol extraction incubated with amyloglucosidase. ${ }^{x}$ Ratio of soluble : insoluble carbohydrates.

Ns,*,**,**** Nonsignificant or significant at $P=0.05,0.01$, or 0.001 , respectively.

Table 3. Chlorophyll fluorescence of 'Seyval blanc' grape leaves 7 days after soil application of paclobutrazol at 0 (control), 1 (treatment 1$), 10$ (treatment 2), 100 (treatment 3), or 1000 (treatment 4) $\mu \mathrm{g}$ a.i./g soil.

\begin{tabular}{lcccc}
\hline & & \multicolumn{3}{c}{ Chlorophyll fluorescence (mA) } \\
\cline { 3 - 5 } Treatment & & Initial & Peak & Terminal \\
\hline Control & Mean & 42.5 & 76.2 & 54.1 \\
& SE & 0.4 & 0.8 & 0.5 \\
1 & Mean & 43.2 & 76.9 & 54.2 \\
& SE & 0.2 & 1.1 & 0.3 \\
2 & Mean & 42.7 & 78.0 & 55.5 \\
& SE & 0.3 & 0.7 & 0.6 \\
3 & Mean & 42.7 & 78.9 & 56.9 \\
& SE & 0.3 & 0.7 & 0.5 \\
4 & Mean & 42.3 & 78.3 & 54.9 \\
& SE & 0.3 & 0.6 & 0.6 \\
Significance & & NS & NS & $* * *$ \\
Linear & & NS & NS & $* *$ \\
Quadratic & & NS & NS & $*$
\end{tabular}

$\overline{\mathrm{NS},{ }^{*, * *, * * * *} \text { Nonsignificant or significant at } P=0.05,0.01 \text {, or } 0.001 \text {, respec- }}$ tively.

J. Amer. Soc. Hort. ScI. 119(3):486-491. 1994. larly the shoot apex, would be reduced, and consequently that there would be a reduction in photosynthetic $\mathrm{CO}_{2}$ uptake (Guinn and Mauney, 1980; Neales and Incoll, 1968). Within 3 to 5 days after applying paclobutrazol, photosynthetic $\mathrm{CO}_{2}$ uptake was reduced and this reduction was maintained for 15 days (Fig. 1). Similar results were obtained when an open system was used to determine photosynthetic light response curves on day 7 after paclobutrazol application (Fig. 2) and from ${ }^{14} \mathrm{CO}_{2}$ uptake data, particularly the short-term feeding study (data not presented). In addition, fresh and dry weights, which are indicative of the cumulative effects of the net $\mathrm{CO}_{2}$ assimilation rate over time, also show a paclobutrazol dose-dependent reduction, particularly for the axillary shoot component (Hunter and Proctor, 1990). Thus, several methods of estimating net photosynthesis rates indicate a consistent response to paclobutrazol treatment.

In the current study, photosynthesis rates were determined on leaves formed before paclobutrazol application. These leaves would therefore be expected to have similar leaf morphology and chlorophyll contents. Previous reports with other plants (Jaggard et al., 1982; Wood, 1984) have indicated that photosynthesis rates increased after paclobutrazol application. However, these authors measured photosynthetic $\mathrm{CO}_{2}$ uptake rates on leaves that formed after treatment with paclobutrazol. Since these leaves typically were smaller, thicker, and darker green, changes in leaf morphology and increases in chlorophyll concentration per unit leaf area likely accounted for the higher rates of photosynthesis observed. In contrast, Vu and Yelenosky (1992) observed no differences in leaf chlorophyll concentration, although leaf photosynthesis rates were reduced at higher levels of paclobutrazol.

A depression in the relative photosynthesis rate of apple leaves formed in the season after paclobutrazol treatment was reported by Steffens and Jacobs (1986). Sink demand for shoot elongation and leaf growth was reduced by paclobutrazol. Demand for assimilates by the developing fruit crop was similar in treated and untreated trees, but there were no indications of redirection of photoassimilates to the developing crop under the heavy fruit load.

Wieland and Wample (1985) reported no significant effect of paclobutrazol on net photosynthetic rate of apple leaves, even though the estimated $\mathrm{CO}_{2}$ uptake for control plants over a 10-h day was almost triple that of soil-treated plants. DeJong and Doyle (1984) noted no apparent effect of paclobutrazol on photosynthetic rate of well-exposed nectarine leaves during most of the growing season.

Leaves are normally exposed to varying levels of irradiance, depending on such factors as leaf position relative to the apex and, 
Table 4. Recovery of ${ }^{14} \mathrm{C}$ and ratio of ethanol-soluble ${ }^{14} \mathrm{C}$ to ethanol-insoluble ${ }^{14} \mathrm{C}$ recovered from 'Seyval blanc' grape plants $24 \mathrm{~h}$ after the photoassimilation of ${ }^{14} \mathrm{CO}_{2}$. Plants were treated with soil-applied paclobutrazol at 0 (control), 1 (treatment 1), 10 (treatment 2), 100 (treatment 3), or 1000 (treatment 4) $\mu \mathrm{g}$ a.i./g soil 7 days before exposure to ${ }^{14} \mathrm{CO}_{2}$.

\begin{tabular}{|c|c|c|c|c|c|c|c|c|c|c|}
\hline \multirow[b]{2}{*}{ Treatment } & & \multirow{2}{*}{$\begin{array}{c}\text { Total } \\
{ }^{14} \mathrm{C} \\
\left(\mathrm{dpm}^{\mathrm{z}} \times 10^{-6}\right)\end{array}$} & \multirow{2}{*}{$\begin{array}{c}\text { Exported } \\
{ }^{14} \mathrm{C} \\
\left(\mathrm{dpm} \times 10^{-6}\right)\end{array}$} & \multirow{2}{*}{$\begin{array}{c}\text { Exported } \\
{ }^{14} \mathrm{C} \\
(\%)\end{array}$} & \multicolumn{6}{|c|}{ Plant component (ratio) } \\
\hline & & & & & Leaf & Petiole & Axil & Stem & Root & Total \\
\hline \multirow{2}{*}{ Control } & Mean & 5.51 & 4.21 & 74.6 & 1.85 & 4.41 & 0.46 & 1.68 & 1.62 & 1.18 \\
\hline & SE & 1.21 & 1.15 & 4.4 & 0.08 & 1.66 & 0.08 & 0.16 & 0.05 & 0.11 \\
\hline \multirow[t]{2}{*}{1} & Mean & 6.62 & 4.84 & 71.8 & 1.35 & 2.99 & 0.57 & 2.10 & 1.34 & 1.24 \\
\hline & SE & 1.52 & 1.16 & 2.7 & 0.17 & 0.97 & 0.14 & 0.42 & 0.17 & 0.22 \\
\hline \multirow[t]{2}{*}{2} & Mean & 7.07 & 4.79 & 67.4 & 1.71 & 5.07 & 0.74 & 2.22 & 1.34 & 1.43 \\
\hline & SE & 0.47 & 0.50 & 2.6 & 0.23 & 0.90 & 0.11 & 0.34 & 0.10 & 0.13 \\
\hline \multirow[t]{2}{*}{3} & Mean & 5.36 & 3.81 & 70.8 & 2.29 & 6.29 & 1.00 & 3.62 & 2.21 & 1.95 \\
\hline & SE & 0.41 & 0.33 & 1.1 & 0.11 & 1.91 & 0.16 & 0.74 & 0.72 & 0.35 \\
\hline \multirow[t]{2}{*}{4} & Mean & 1.83 & 1.01 & 54.7 & 2.54 & 6.14 & 1.93 & 5.97 & 6.02 & 2.98 \\
\hline & SE & 0.22 & 0.13 & 1.1 & 0.35 & 1.75 & 0.28 & 1.56 & 3.24 & 0.56 \\
\hline Significance & & $* *$ & $* *$ & $* * *$ & $*$ & NS & $* * *$ & $*$ & NS & $* *$ \\
\hline Linear & & $* *$ & $*$ & $* * *$ & $* *$ & NS & $* * *$ & $* *$ & NS & $* *$ \\
\hline Quadratic & & $* *$ & * & $*$ & $*$ & NS & $*$ & NS & NS & NS \\
\hline
\end{tabular}

${ }_{\mathrm{Z}} \mathrm{DPM}=$ DISINTEGRATIONS PER MINUTE.

ss, ${ }^{*},{ }^{* *},{ }^{* * *}$ Nonsignificant or significant at $P=0.05,0.01$, or 0.001 , respectively.

Table 5. Distribution of exported ${ }^{14} \mathrm{C}$ (as percentage of exported ${ }^{14} \mathrm{C}$ recovered) in 'Seyval blanc' grape plants $24 \mathrm{~h}$ after photoassimilation of ${ }^{14} \mathrm{CO}_{2}$. Plants were treated with soil-applied paclobutrazol at 0 (control), 1 (treatment 1), 10 (treatment 2), 100 (treatment 3), or 1000 (treatment 4) $\mu \mathrm{g}$ a.i./g soil 7 days before exposure to ${ }^{14} \mathrm{CO}_{2}$.

\begin{tabular}{|c|c|c|c|c|c|}
\hline \multirow[b]{2}{*}{ Treatment } & & \multicolumn{4}{|c|}{ Distribution of exported ${ }^{14} \mathrm{C}(\%)$} \\
\hline & & Petiole & Axil & Stem & Root \\
\hline \multirow[t]{2}{*}{ Control } & Mean & 1.4 & 37.4 & 18.1 & 43.1 \\
\hline & SE & 0.2 & 4.6 & 1.1 & 5.2 \\
\hline \multirow[t]{2}{*}{1} & Mean & 1.8 & 22.0 & 19.3 & 56.9 \\
\hline & SE & 0.4 & 6.6 & 1.1 & 5.6 \\
\hline \multirow[t]{2}{*}{2} & Mean & 2.2 & 17.3 & 18.6 & 61.9 \\
\hline & SE & 0.3 & 2.9 & 2.1 & 2.6 \\
\hline \multirow[t]{2}{*}{3} & Mean & 2.0 & 28.7 & 19.0 & 50.3 \\
\hline & SE & 0.3 & 5.9 & 2.4 & 4.3 \\
\hline \multirow[t]{2}{*}{4} & Mean & 3.4 & 26.5 & 21.6 & 48.5 \\
\hline & SE & 0.4 & 2.9 & 2.3 & 3.2 \\
\hline Significance & & $* *$ & NS & NS & NS \\
\hline Linear & & $* * *$ & NS & NS & NS \\
\hline Quadratic & & NS & * & NS & * \\
\hline
\end{tabular}

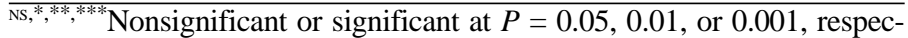
tively.

in the case of field-grown grapevines, to canopy architecture and position in the leaf canopy. The dependence of photosynthesis on irradiance is nonlinear, and, in the current study, an asymptotic exponential (Goudriaan, 1979) had the best fit.

Apparently, while photosynthetic $\mathrm{CO}_{2}$ uptake was reduced by paclobutrazol, dark respiration was not affected (Fig. 2). Photosynthetic light compensation points for mature leaves of two interspecific hybrids (V-50201 and 'De Chaunac') were $\approx 25 \mu \mathrm{mol}$ $\mathrm{m}^{-2} \mathrm{~s}^{-1}$, and light saturation had not been reached at a PPF of 780 $\mu \mathrm{mol} \cdot \mathrm{m}^{-2} \cdot \mathrm{s}^{-1}$ (Fisher, 1988). Düring (1988) reported light compensation points between 6 and $24 \mu \mathrm{mol} \cdot \mathrm{m}^{-2} \cdot \mathrm{s}^{-1}$ for $3 \mathrm{~V}$. vinifera cultivars (Riesling, Trollinger, and Phoenix) and light saturation at $\approx 550 \mu \mathrm{mol} \cdot \mathrm{m}^{-2} \cdot \mathrm{s}^{-1}$, with further increases in light intensity to 2250 $\mu \mathrm{mol} \cdot \mathrm{m}^{-2} \cdot \mathrm{s}^{-1}$, resulting in only a slight $(<15 \%)$ increase in photosynthetic $\mathrm{CO}_{2}$ uptake rate. These results are consistent with those obtained in the present study from single-leaf test plants not treated with paclobutrazol.
Changes in sink demand for photoassimilates can affect the proportion of recent photoassimilates converted to starch in the leaf. Photoassimilates in excess of current demands are converted into starch for temporary storage, and buildup of leaf starch can lead to a feedback inhibition of photosynthesis (Guinn and Mauney, 1980; Neales and Incoll, 1968). In the present study, photosynthesis rate was reduced after paclobutrazol application, resulting in less photoassimilates being available in excess of current demands for partitioning into starch. Thus, an increasing proportion of photoassimilates was retained in a soluble form with increasing paclobutrazol doses (Tables 2 and 4).

When a dark-adapted leaf is illuminated, photosynthetic processes are activated, passing through several transient stages before reaching steady state, and chlorophyll $a$ fluorescence is a nondestructive method of observing some of these processes (Papageorgiou, 1975). Chlorophyll fluorescence parameters have been widely used, particularly in herbicide research, to indicate inhibition of electron transport between photosystem II and photosystem I (Ali and Souza Machado, 1981). In the current study, no significant differences in initial or peak values were observed (Table 3). The increase in terminal fluorescence values as paclobutrazol dose increased from 0 to $100 \mu \mathrm{g}$ a.i./g soil may indicate an increasing, although small, inhibition of photosynthetic electron transport. At the highest paclobutrazol dose $\left(1000 \mu \mathrm{g} \cdot \mathrm{g}^{-1} \mathrm{soil}\right)$, there was a small reduction in terminal fluorescence value. Extended exposure to photosynthetic inhibitors resulted in the destruction of chloroplasts and the loss of their ability to emit fluorescence (Shaw et al., 1986).

In conclusion, paclobutrazol inhibited vegetative growth, thus altering the demand for photoassimilates by the vegetative shoot apex. On a whole-plant basis, the total supply of photoassimilates was decreased by a reduction in photosynthetic leaf area and also by an inhibition of $\mathrm{CO}_{2}$ uptake rate. The inhibition in photosynthesis rate could not be attributed to a buildup of starch in the leaves. Even though paclobutrazol treatment altered sink strength and, hence, the allocation of photoassimilates in the plant, growth responses observed after paclobutrazol treatment resulted from the integration of several effects including, but not limited to, effects on gibberellin biosynthesis, $\mathrm{C}$ metabolism, stomatal function, and general plant metabolism. Grapevine canopy manipulation can 
improve the light environment in the canopy, thus contributing to increased production, improved fruit quality, and uniformity of ripening, while the time required for pruning can be reduced. Additional work is required to determine the physiological basis for the effects of paclobutrazol on plant carbohydrate metabolism and $\mathrm{C}$ allocation in the plant and to determine the optimum application time and doses for practical use.

\section{Literature Cited}

Ali, A. and V. Souza Machado. 1981. Rapid detection of triazine resistant weeds using chlorophyll fluorescence. Weed Sci. 21:191-197.

DeJong, T.M. and J.F. Doyle. 1984. Leaf gas exchange and growth responses of mature 'Fantasia' nectarine trees to paclobutrazol. J. Amer. Soc. Hort. Sci. 109:878-882.

Düring, H. 1988. $\mathrm{CO}_{2}$ assimilation and photorespiration of grapevine leaves: Responses to light and drought. Vitis 27:199-208.

Fisher, K.H. 1988. The interaction of vine morphology and row and vine spacing on the productivity of five interspecific grapevine cultivars. $\mathrm{PhD}$ diss. Cornell Univ., Ithaca, N.Y.

France, J. and J.H.M. Thornley. 1984. Mathematical models in agriculture. A quantitative approach to problems in agriculture and related sciences. Butterworths, London.

Gaynor, J.D. 1984. Diclofop-methyl persistence in southwestern Ontario soils and effect of $\mathrm{pH}$ on hydrolysis and persistence. Can. J. Soil Sci. 64:283-291.

Goudriaan, J. 1979. A family of saturation type curves, especially in relation to photosynthesis. Ann. Bot. 43:783-785.

Grant, J.A. and K. Ryugo. 1984. Influence of within-canopy shading on fruit size, shoot growth, and return bloom in kiwifruit. J. Amer. Soc. Hort. Sci. 109:799-802.

Guinn, G. and J.R. Mauney. 1980. Analysis of $\mathrm{CO}_{2}$ exchange assumptions: Feedback control, p. 1-16. In: J.D. Hesketh and J.W. Jones (eds.). Predicting photosynthesis for ecosystem models. vol. 2. CRC Press, Boca Raton, Fla.

Hale, C.R. and R.J. Weaver. 1962. The effect of developmental stage on direction of translocation of photosynthate in Vitis vinifera. Hilgardia 33:89-131.

Hunter, D.M. and J.T.A. Proctor. 1990. Paclobutrazol bioassay using the axillary growth of a grape shoot. HortScience 25:309-310.

Hunter, D.M. and J.T.A. Proctor. 1992. Paclobutrazol affects growth and fruit composition of potted grapevines. HortScience 27:319-321.

Jaggard, K.W., D.K. Lawrence, and P.V. Biscoe. 1982. An understanding of crop physiology in assessing a plant growth regulator on sugar beets, p. 139-150. In: J.S. McLaren (ed.). Chemical manipulation of crop growth and development. Butterworths, London.

Koblet, W. 1977. Translocation of photosynthate in grape vines, p. 45-51. In: P. Huglin (ed.). Proc. Intl. Symp. Quality of the Vintage. Capetown, South Africa.
Koblet, W. 1985. Influence of light and temperature on vine performance in cool climates and applications to vineyard management, p. 139-157. In: D.A. Heatherbell, P.B. Lombard, F.W. Bodyfelt, and S.F. Price (eds.). Proc. Intl. Symp. Cool Climate Viticult. and Enol. Corvallis, Ore.

Mansfield, T.K. and G.S. Howell. 1981. Response of soluble solids accumulation, fruitfulness, cold resistance, and onset of bud growth to differential defoliation stress at veraison in Concord grapevines. Amer. J. Enol. Viticult. 32:200-205.

Neales, T.F. and L.D. Incoll. 1968. The control of leaf photosynthesis rate by the level of assimilate concentration in the leaf: A review of the hypothesis. Bot. Rev. 34:107-125.

Papageorgiou, G. 1975. Chlorophyll fluorescence: An intrinsic probe of photosynthesis, p. 320-366. In: Govindjee (ed.). Bioenergetics of photosynthesis. Academic Press, New York.

Proctor, J.T.A., J.M. Bodnar, W.J. Blackburn, and R.L. Watson. 1982. Analysis of the effect of the spotted tentiform leafminer (Phyllonorycter blancardella) on photosynthetic characteristics of apple leaves. Can. J. Bot. 60:2734-2740.

Reynolds, A.G. 1988. Inhibition of lateral shoot growth in summer-hedged 'Riesling' grapevines by paclobutrazol. HortScience 23:728-730.

Ross, G.J.S. 1987. Maximum likelihood program. Numerical Algorithm Group, Oxford, England.

Shaltout, A.D., A.T. Salem, and A.S. Kilany. 1988. Effect of pre-bloom sprays and soil drenches of paclobutrazol on growth, yield and fruit composition of 'Roumi Red' grapes. J. Amer. Soc. Hort. Sci. 113:13-17.

Shaw, D.R., T.F. Peeper, and D.L. Nofziger. 1986. Evaluation of chlorophyll fluorescence parameters for an intact-plant herbicide bioassay. Crop Sci. 26:756-760.

Snedecor, G.W. and W.G. Cochran. 1980. Statistical methods. 7th ed. Iowa State Univ. Press, Ames.

Steffens, G.L. and F.W. Jacobs. 1986. The influence of GA inhibitors on photosynthesis in apple trees. Proc. Plant Growth Regulat. Soc. Amer. 13:182.

Ursino, D.J., D.M. Hunter, R.D. Laing, and J.L.S. Keighley. 1982. Nitrate modification of photosynthesis and photoassimilate export in young nodulated soybean plants. Can. J. Bot. 60:2665-2670.

$\mathrm{Vu}$, J.C.V. and G. Yelenosky. 1992. Growth and photosynthesis of sweet orange plants treated with paclobutrazol. J. Plant Growth Regulat. 11:85-89.

Wample, R.L. and E.B. Culver. 1983. The influence of paclobutrazol, a new growth regulator, on sunflower. J. Amer. Soc. Hort. Sci. 108:122125.

Wieland, W.F. and R.L. Wample. 1985. Effects of paclobutrazol on growth, photosynthesis and carbohydrate content of 'Delicious' apples. Scientia Hort. 26:139-147.

Williams, L.E., P.J. Biscay, and R.J. Smith. 1989. The effect of paclobutrazol injected into the soil on vegetative growth and yield of Vitis vinifera L., cv. Thompson seedless. J. Hort. Sci. 64:625-631.

Wood, B.W. 1984. Influence of paclobutrazol on selected growth and chemical characteristics of young pecan seedlings. HortScience 19:837839. 